\title{
The Formation of the Militia in the February Revolution: An Aspect of the Origins of Dual Power
}

The insurrection on February 27, 1917, totally annihilated the tsarist police system in Petrograd, the most important link tying the citizens to the government, thus throwing the capital into a state of anarchy. Quickly lawlessness crept into the streets, as drunken soldiers looted wine cellars to get even more drunk and criminals released from prisons easily acquired weapons. ${ }^{1}$ To the sober-minded, it was apparent that this intolerable disorder had to be stopped as quickly as possible. Yet, for the more committed revolutionaries, the insurrection was not yet finished; even on February 28 machine-gun shots were fired from rooftops and upper-floor windows of tall buildings-actions, people firmly believed, taken by the remnants of Protopopov's police or the counterrevolutionary officers. ${ }^{2}$ Whether for the restoration of law and order or for the defense of the revolution, Petrograd urgently needed an organized police force. Indeed, the future course of the revolution to a large extent depended on how the new police force would be organized. If a group which regarded the restoration of law and order as the most urgent task established an efficient police power in the streets, it would mean that the revolutionary process that had been set in motion would be halted. On the other hand, if the revolutionaries succeeded in arming the masses of insurgents for the defense of the revolution, that would surely mean the further intensification of the revolutionary process. An analysis of the formation of the militias in the February Revolution is, therefore, integrally related to the problem of power. ${ }^{3}$

1. A. V. Peshekhonov, "Pervyia nedeli; Iz vospominanii o revoliutsii," Na chuzhoi storone, 1 (1923): 272-74. Also see various reports on looting to the Military Commission of the Duma Committee, "Fevral'skaia revoliutsiia v Petrograde (28 fevralia-1 marta 1917 g.)," Krasnyi arkhiv, 1930, no. 4-5 (41-42), pp. 65, 66, 71, 74.

2. "Fevral'skaia revoliutsiia v Petrograde," pp. 63, 64, 67, 75, 76, 77.

3. The military question-or the soldatskii vopros, as it was put at the time-was a more important issue than the problem of militias in its direct bearing on the formation of a revolutionary power. The sequence of events from the formation of the Military Commission to the issuance of Order No. 1 and its aftermath and the respective attitudes of the Duma Committee, the Soviet Executive Committee, and the masses of soldiers toward the soldatskii vopros must be studied in detail and analyzed critically. That problem, however, is beyond the scope of this article.

The author wishes to thank the Research Foundation of the State University of New York for a faculty research fellowship which made the preparation of this article possible. 
The February Revolution created two centers of power-the Provisional Government and the Petrograd Soviet-rather than producing a single revolutionary power. This unique situation became known as dual power (dvoevlastie $){ }^{4}$ In attempting to analyze the origins of dual power, historians in the West have narrowly focused their attention on the relation between the Soviet Executive Committee and the Duma Committee, the parent body of the Provisional Government. A careful study of the interaction between these two bodies and the mass movement at the bottom, an essential prerequisite for a better understanding of the problem, has not been done. ${ }^{5}$ This article is an attempt to throw some light on the complexities involved in the process of the birth of dual power by examining the tripartite relations between the Soviet Executive Committee, the Duma Committee, and the Petrograd workers in the formation of the militia in the February Revolution. ${ }^{6}$

At the first general session of the Petrograd Soviet, convened at nine o'clock on the evening of February 27 in Tauride Palace, M. A. Braunstein, a Menshevik, introduced a motion to form a militia "in order to restore order and direct the struggle against anarchy and pogroms." It is important to note that the maker of the motion defined the principal task of the militia as the restoration of order. According to N. N. Sukhanov, who seconded the motion, this proposal did not encounter any opposition, but "provoked some misunderstandings and amendments." Some delegates wanted to include offensive actions by the militia against the remaining forces of tsarism. Sukhanov "defended Braunstein's motion, reminding the audience of the existence of the Military Commission and cautioning against confusion of functions and authorities." The general session adopted the original motion, directing the

4. For the analysis of the birth of dual power see my article, "The Problem of Power in the February Revolution of 1917 in Russia," Canadian Slavonic Papers, 14, no. 4 (Winter 1972): 611-32.

5. See, for instance, Leonard Schapiro, "The Political Thought of the First Provisional Government," Oskar Anweiler, "The Political Ideology of the Leaders of the Petrograd Soviet in the Spring of 1917," and Bertram D. Wolfe's "Comment" on these two articles in Richard Pipes, ed., Revolutionary Russia (Cambridge, Mass., 1968). Although Wolfe acknowledges the importance of the mass movement, his analysis does not go beyond a mere designation of the term stikhiia to it. A notable exception is a study of the origins of Order No. 1 by John Boyd, who, utilizing the recent achievements by Soviet historians, particularly V. I. Miller, illuminates the interaction between the two centers of power at the top and the masses of soldiers at the bottom. See John R. Boyd, "The Origins of Order No. 1," Soviet Studies, 19, no. 3 (January 1968) : 359-72.

6. I should mention here a little-known but significant article by a Japanese historian, Wada Haruki, "Nigatsu kakumei" ("The February Revolution"), in Eguchi Bokuro, ed., Roshiya kakumei no kenkyu ( $A$ Study of the Russian Revolution) (Tokyo: Chuo koron sha, 1968). Although I differ with the author on a number of points, this article makes an important contribution to the historiography of the February Revolution. Wada also discusses the problem of militia, but his treatment is descriptive rather than analytical, without specifically relating this problem directly to the origins of dual power. 
workers to form a militia of one hundred workers for every thousand in each factory, and empowering the Executive Committee to appoint a commissar in each city district to organize a district militia. ${ }^{7}$ The Executive Committee meeting held immediately after the general session elaborated on its decision by appointing ten district commissars and designating headquarters in each district, where the workers and the soldiers were urged to gather. ${ }^{8}$ The appointed commissars, with the exception of Peshekhonov, do not appear to have played a significant role in creating a district militia, however. A. Shliapnikov, appointed commissar for the Vyborg District and the most important leader of the Bolshevik Party at that time, recalls that when these commissars met after the Executive Committee meeting, they had neither experience nor familiarity with the localities. The meeting "therefore bore a theoretical character," rather than dealing with practical problems. ${ }^{9}$ Shliapnikov himself, totally immersed in the activities of the Executive Committee and of the party, had no time to spend on the organization of a militia. In fact, the Petrograd Soviet's decision to form a militia would have dissipated had it not been followed up by the workers' enthusiastic support.

Since the Duma Committee recognized that the restoration of order in the streets was one of the most important prerequisites for the creation of a stable government, it immediately took the initiative in creating a militia. On February 28 it dismissed General A. P. Balk as the Petrograd gradonachal'nik and appointed Professor V. Iurevich of the Military Medical Academy to that post, which was renamed obshchestvennyi gradonachal'nik to signify a break with the past administration. The task of the obshchestvennyi gradonachal'nik, Iurevich declared, was "to insure the personal safety of citizens and of their property" and to establish committees "for security of order and for the food supply for citizens."10 Since it turned out to be impossible, however, to estab-

7. N. N. Sukhanov, Zapiski o revoliutsii, 7 vols. (Berlin, Petrograd, and Moscow, 1922-23), 1:132.

8. At least three persons can be identified as appointed commissars: A. Shliapnikov (Bolshevik) for the Vyborg District, A. V. Peshekhonov (Popular Socialist) for the Petrograd District, and Surin (Socialist Revolutionary) for the Lesnoi District. See A. Shliapnikov, Semnadtsatyi god, 4 vols. (Moscow and Petrograd, 1923-31), 1:154. Later Surin was discovered to be a former tsarist Okhrana agent. See V. M. Zenzinov, "Fevral'skie dni," Novyi Zhurnal, no. 35 (1953), p. 220. Peshekhonov was not informed of this decision until the following day (Peshekhonov, "Pervyia nedeli," p. 266). The places designated as district headquarters were known as the legal centers of the workers' organizations before the revolution, such as the offices of the workers' sick-funds and cooperative associations in major factories, the stock markets, a night school, dining halls of major factories, and the office of social work. Only seven district headquarters were designated. See Izvestiia Petrogradskogo Soveta rabochikh depufatov (hereafter Izvestiia), supplement to no. 1 (Feb. 28, 1971).

9. Shliapnikov, Semnadtsatyi god, 1:154.

10. Izvestiia revolintsionnoi nedeli, no. 2 (Feb. 28, 1917). 
lish a militia on the basis of the administrative structure of the gradonachal'stvo, which had been completely disrupted by the destruction of the police, Iurevich had to entrust D. A. Kryzhanovsky, a member of the City Duma and an architect, with the job. ${ }^{11}$ Thus the initiative to create a militia was transferred from the gradonachal'stvo to the City Duma, which decided to create a city militia (gorodskaia militsiia), "in the interests of the assurance of life and property of the population," at the emergency meeting held at eight in the evening. ${ }^{12}$ This meeting also confirmed Kryzhanovsky as head of the city militia, and approved that expenses be appropriated from the city budget. ${ }^{13}$ At the same time, the City Duma authorized appointed district representatives to initiate the creation of the city militia and designated the specific locations for the district headquarters. Most of the district representatives were selected from the City Duma members, but for the Vyborg District two students of the Military Medical Academy, V. G. Botsvadze and a certain Shvakhtsaboy, together with two City Duma members, received the authorization to form the militia -a recognition that the City Duma members alone could not carry much influence in the workers' section. ${ }^{14}$ In response to the appeal of the City Duma, many educational and technical institutions supported the creation of the city militia. The Committee of the Military-Technical Aides, one of the most active supporters of the city militia, defined the task of the militia in its appeal issued on February 28 as follows: "(1) elimination of useless shooting, (2) confiscation of weapons from juveniles and drunkards, (3) prevention of looting, and (4) enforcement of order in the streets and public places."15 The mayor of the city, Iu. N. Glebov, elected by the City Duma on February 28 to replace his predecessor, N. N. Lelianov, generously offered the mayor's office as the central headquarters of the city militia, and appropriated ten thousand rubles from the city budget for its operation. ${ }^{16} \mathrm{Z}$. Kelson, who became secretary of

11. Ibid. The Military Commission of the Duma Committee also appointed Kryzhanovsky head of the city militia ("Fevral'skaia revoliutsiia v Petrograde," p. 99).

12. E. N. Burdzhalov, Vtoraia russkaia revoliutsiia: Vosstanie v Petrograde (Moscow, 1967), p. 272. See also Rech', no. 55 (Mar. 5, 1917), p. 3.

13. Burdzhalov, Vtoraia russkaia revoliutsiia, p. 272.

14. Z. Kel'son, "Militsiia fevral'skoi revoliutsii: Vospominaniia," Byloe, 29 (1925): 162. It is not certain if the City Duma designated district headquarters for all the districts in Petrograd. Kel'son mentions only four district centers. It is interesting to compare this list with the list of district headquarters designated by the Soviet Executive Committee. While the Soviet concentrated on the workers' sections, the City Duma placed its emphasis on the administrative center of the city.

15. Burdzhalov, Vtoraia russkaia revolintsiia, p. 272 . The other institutions which supported the city militia were the United Russian Technical Society, the Society of Technology, Electronic Engineers, and Civil Engineers, and the Metallurgical Society.

16. Kel'son, "Militsiia fevral'skoi revoliutsii," p. 162; Rech', no. 55 (Mar. 5, 1917), p. 3. Later, on March 11, the central headquarters of the city militia were transferred to the gradonachal'stvo. 
the city militia on the recommendation of a Menshevik member of the Soviet Executive Committee, B. D. Bogdanov, organized the administrative work of the city militia, mobilizing the female employees of the City Duma, wives of the Duma members, boy scouts, and high school students. ${ }^{17}$ The city militia as of March 5 numbered seven thousand, drawing its main strength from civil servants and university and high school students. ${ }^{18}$

By March 1, therefore, two centers of militia organizations came into existence in Petrograd, the one organized by the Petrograd Soviet and the other organized by the City Duma. How, then, did the workers in Petrograd react to this situation? Even before the Petrograd Soviet's decision to create a militia, the workers who had actively participated in the insurrection had taken the initiative and formed a workers' militia. As early as February 25 the factory committee in the Putilov Factory had passed a resolution calling for the formation of a detachment of armed workers (boevaia druzhina) in order to "establish order and disarm the police in the Narva District."19 On February 27 at least three groups of insurgent workers attempted to create a militia; and in two cases out of these three the creation of a militia directly resulted from the workers' struggle against the police. ${ }^{20}$ This militant desire to destroy the old order and establish their own autonomous power underscored the principal purpose of the workers' militia thereafter-a purpose far more important in their minds than the mere restoration of order and the struggle against lawlessness and anarchy.

It was in this highly charged atmosphere that the Petrograd Soviet's decision served as a catalyst, causing an unexpected and overwhelming reaction from the workers. The chemical and metal workers in the Vyborg District, who had been the driving force of the strike and the demonstration during the February Revolution, were the first to respond to the appeal of the Petrograd Soviet. The formation of a militia in the Vyborg District was already reported at the second session of the Soviet on February $28,{ }^{21}$ although it began to take definite shape only on March 1 with the participation of the workers from major factories. The militia organized by about 250 workers of Old Rozenkrants absorbed similar militia organizations formed in the neighboring factories-the Metal Factory, the Arsenal, the Phoenix, and others-and

17. Kel'son, "Militsiia fevral'skoi revoliutsii," p. 163. p. 3.

18. Burdzhalov, Vtoraia russkaia revoliutsiia, p. 272; Rech', no. 55 (Mar. 5, 1917),

19. I. P. Leiberov, "Petrogradskii proletariat vo vseobshchei politicheskoi stachke 25 fevralia $1917 \mathrm{~g}$.", in Oktiabr' i grazhdanskaia voina v SSSR: Sbornik statei $k$ 70letiiu akademika I. I. Mintsa (Moscow, 1966), p. 39.

20. V. I. Startsev, Ocherki po istorii Petrogradskoi Krasnoi gvardii i rabochei militsii (Moscow and Leningrad, 1965), pp. 43-44.

21. G. I. Zlokazov, "O zasedanii Petrogradskogo Soveta rabochikh i soldatskikh deputatov," in Oktiabr' i grazhdanskaia voina v SSSR, p. 50. 
established the First Vyborg Subdistrict Commissariat, appointing Botsvadze, dispatched by the City Duma, as the first commissar. ${ }^{22}$ Botsvadze had gained great popularity and trust among the workers, because he had participated with them in the attacks on the Kresty prison and the House of Detention on February $27 .^{23}$ Since the rest of the representatives appointed by the City Duma quickly lost their effectiveness, one can safely assume that Botsvadze's appointment as commissar stemmed from his ability to identify with the workers rather than from the authority of the City Duma. Later, however, as the conflict between the workers' militia and the city militia sharpened, the presidium of the commissariat dismissed Botsvadze. ${ }^{24}$

Also on March 1 major factories in the Second Vyborg Subdistrict along the Sampsonievsky Prospekt organized militia organizations. In New Lessner about fifty workers registered in the militia, which immediately engaged in patrols in neighboring streets; in Old Lessner the militia, joined by more than 250 workers, occupied the Sampsonievsky Bridge and the adjoining streets. ${ }^{25}$ These militia organizations merged with others formed in such major factories as New Parviainen, Erikson, Aivaz, and Old Parviainen, and created the Second Vyborg Subdistrict Commissariat. ${ }^{26}$ It is reported that some soldiers from the Reserve Battalion of the Moscow Regiment and the First Machine Gun Regiment joined the workers' militia in this subdistrict. ${ }^{27}$ The workers' militia was organized in the Porokhovye District north of Okhta and the Vyborg District outside the city limit, where two large gunpowder factories were located. On February 28 the workers of these factories formed the Executive Commission of the District Soviet, which organized the militia, "immediately occupying the paralyzed local power, disarming police, factory officials, and removing sentinel posts." 28

While the workers completely controlled the militia organizations in the Vyborg District, on Vasilievsky Island the workers' militia coexisted side by side with the city militia. On February 28 the Military Commission of the Duma Committee appointed Professor V. V. Nikitin of the Mining Institute to organize a militia on Vasilievsky Island "for the restoration and the maintenance of order." ${ }^{29}$ Whether Professor Nikitin's influence had a direct bearing or not, the students of the Mining Institute formed an organizational

22. Startsev, Ocherki po istorii Petrogradskoi Krasnoi gvardii, pp. 43-44; Kel'son, "Militsiia fevral'skoi revoliutsii," p. 175.

23. Kel'son, "Militsiia fevral'skoi revoliutsii," p. 175.

24. Startsev, Ocherki po istorii Petrogradskoi Krasnoi gvardii, p. 56.

25. Ibid., p. 44.

26. Ibid. The formation of a militia in the factories Aivaz and Old Parviainen was reported in Izvestiia, no. 3 (Mar. 2, 1917), p. 3.

27. Startsev, Ocherki po istorii Petrogradskoi Krasnoi gvardii, p. 44.

28. Raionnye sovety Petrograda v 1917 godu, 3 vols. (Moscow, 1966), 3:180-81.

29. "Fevral'skaia revoliutsiia v Petrograde," p. 96. 
committee composed of fifteen students and three professors at a general meeting held on February 28 . The organizational committee formed a militia among other specifically designated commissions. ${ }^{30}$ Although the chairman of this committee expressed a wish to keep contact with the Petrograd Soviet, it appears likely that this militia was absorbed into the city militia, which established the First Vasilievsky Commissariat under its head, Judge Drozdov. ${ }^{31}$ This commissariat restored order in the area along the Bolshoi Prospekt and regularly dispatched the patrols, each composed of ten soldiers under the leadership of one student. ${ }^{32}$ In three other subdistricts, however, the workers' militia took the upper hand. ${ }^{33}$ In the Second Vasilievsky Subdistrict, where large factories were concentrated, the militia organized by the workers of the large plants-the Pipe Factory, Simens-Haliske, Vasilievsky Railway Cars, Possel, and others-occupied the police station on Line Five and established the commissariat there. A Bolshevik, Sergeev, became the first commissar. ${ }^{34}$ Although the workers' militia controlled the Third Vasilievsky Subdistrict as well, with an S.R. student named Medvedsky as its first commissar, its strength appears to have been less than the counterparts in the Second and Fourth Subdistricts. The Cable Factory constituted the major force in the militia organization in the Fourth Vasilievsky Subdistrict, also known as the Harbor Subdistrict. The workers of this factory selected the militia members at a general meeting held on March 1 and passed a resolution demanding that the Petrograd Soviet transfer weapons to the district soviet. ${ }^{35}$ The workers' militia on Vasilievsky Island worked in close cooperation with the Vasilievsky District Soviet, which appointed an S.R. member, Alekseev, chief of the Militia Commission. The coexistence of the workers' militia and the city militia inevitably led to constant friction between the two organs. Under the pressure of the workers' militia, the Executive Commission of the District Soviet established a supervisory commission specifically to watchdog the activities of the city militia in the first subdistrict. ${ }^{38}$

The situation was even more complicated in the Petrograd District, where

30. Isvestiia, no. 2 (Mar. 1, 1917), p. 3.

31. Startsev, Ocherki po istorii Petrogradskoi Krasnoi gvardii, p. 43; Raionnye sovety Petrograda, 1:365.

32. Izvestiia, no. 4 (Mar. 3, 1917), p. 4. It is significant that Izvestiia elected to describe the formation of the city militia and totally ignored the workers' militia in the Vasilievsky District.

33. Raionnye sovety Petrograda, 1:365.

34. Startsev, Ocherki po istorii Petrogradskoi Krasnoi gvardii, p. 45. Sergeev was replaced by another Bolshevik, Ivanov, in late March.

35. Velikaia Oktiabr'skaia Sotsialisticheskaia Revoliutsiia: Dokumenty i materialy, 6 vols. (Moscow, 1957-59), vol. 1: Revoliutsionnoe dvizhenie v Rossii posle sverzheniia samoderzhaviia (Moscow, 1957), pp. 455-56.

36. Raionnye sovety Petrograda, 1:73. 
not only the workers' militia and the city militia but also the militia organized by the commissar appointed by the Soviet Executive Committee competed with one another. The machinists of Langenzippen Machine Factory constituted the nucleus of the workers' militia in this district, but its strength hardly matched the two competing organizations. The workers' militia here failed even to create an independent commissariat. At first it created a militia center in House 15 on Oranienbaum Street, but soon the Second Petrograd Subdistrict Commissariat of the city militia moved in, establishing its headquarters there. Having lost its center, the workers' militia decided to create a commissariat and moved into one room of House 18 on Bolshoi Belozerskaia Street, where the First Petrograd Subdistrict Commissariat of the city militia, and its AllDistrict Commissariat, had established their headquarters. ${ }^{37}$ The transfer of the office of the workers' militia to the headquarters of the city militia strongly indicates that either it completely merged with the city militia or at least it maintained very close cooperation with it.

Neither the workers' militia nor the city militia, however, had great influence in the Petrograd District. These two militias were eventually absorbed into the commissariat organized by Peshekhonov, the commissar appointed by the Soviet Executive Committee. A. V. Peshekhonov, a member of the Popular Socialist Party as well as a member of the Soviet Executive Committee and of its Literary Commission, represented the right wing of the Executive Committee. When he accepted the appointment as commissar of the Petrograd District on February 28, he sought to obtain authority from the Duma Committee as well. But the Duma Committee leader Miliukov refused this authorization, for, according to Peshekhonov, the Duma Committee had not come to grips with the importance of extending its authority to the local level. ${ }^{38}$ It is unlikely that Miliukov failed to appreciate this problem; in fact, he was keenly aware of the dangers of dual power. ${ }^{39}$ His refusal stemmed not from his ignorance but from his determined efforts not to lend any support to the authority of the Petrograd Soviet.

After establishing his headquarters in a movie theater, the Elite, at the corner of Kamenoostrovsky and Bolshoi Prospekts, Peshekhonov immediately issued a proclamation to the populace in the Petrograd District in which he appealed to them "to maintain calm despite the developing events, to react

37. Startsev, Ocherki po istorii Petrogradskoi Krasnoi gvardii, p. 44.

38. Peshekhonov, "Pervyia nedeli," pp. 266-67.

39. After the Duma Committee's decision to take power, Miliukov devoted all his energy to establishing sole legitimacy for the new government, avoiding the interference of the Petrograd Soviet. In his speeches addressed to the soldiers on February 28 he warned of the danger of "dual power"-a term that was used first by him and later acquired wide currency. See Izvestiia revoliutsionnoi nedeli, no. 2 (Feb. 28, 1917). 
with trust to the district commissars appointed by the new power [which he did not specify, probably intentionally] and execute their orders, and to fulfill the obligations necessary for public service." ${ }^{30}$ The proclamation also urged factories, mills, and other social organizations to send their delegates to the commissariat. It is apparent that Peshekhonov mainly concerned himself with the restoration of order. Responding to the proclamation, which was distributed throughout the district, a few hundred volunteers, including intelligentsia, workers, and soldiers, assembled at the commissariat, and formed a militia. ${ }^{41}$

Peshekhonov's commissariat established itself as the most influential authority in the Petrograd District by absorbing some organizations and subordinating others. He entered into negotiations with a group of intellectuals who had organized a commissariat on February 28 and occupied the building of the city council (gorodskaia uprava) as their headquarters. This group agreed to be incorporated into Peshekhonov's commissariat. ${ }^{42}$ A similar organization, which came into existence on Krestovsky Island, pledged allegiance to the commissariat while maintaining its separate entity. ${ }^{43}$ Another organization by the name of the "citizens' committee" also claimed autonomous local power. This committee was organized by the liberal intellectuals calling themselves the "progressive-democratic group," who had engaged in the election campaign in the City Duma at the last election before the revolution-a group, we can assume, closely identified with the Progressive Bloc in the Fourth Duma. The entire district was divided into sixteen to eighteen subdistricts, each of which held citizens' meetings. The citizens-men and women over twenty-elected their representatives to the citizens' committee. Peshekhonov did not attempt to take over this organization, believing that he could come to terms with it in case of conflict. ${ }^{44}$ Peshekhonov also negotiated with the commandant appointed by the Military Commission of the Duma Committee, an aristocrat officer of the Grenadier Regiment with a lethargic personality. The authority of this commandant remained extremely ineffective, to the extent that Peshekhonov had no knowledge of his existence until a few days after his appointment. Peshekhonov declared to him that, not wishing to create a dual power, he was prepared to accept his authority on the conditions that the commandant's office be transferred to the commissariat and that the commandant

40. Izvestiia, no. 2 (Mar. 1, 1917), p. 3. The same proclamation with a slight change was also printed in Irvestiia, no. 3 (Mar. 2, 1917), p. 4.

41. Peshekhonov, "Pervyia nedeli," p. 271.

42. Ibid., p. 304.

43. Ibid., pp. $304-5$.

44. Ibid., p. 305. It is not known how widespread the election for the citizens' committee was in the district, what relations it established with the Duma Committee or the city militia, what happened to it subsequently, or whether similar organizations existed in other districts in Petrograd. 
work in constant contact with Peshekhonov. The commandant gladly accepted these conditions and never interfered in the work of the commissariat. ${ }^{45}$

Thus in the Petrograd District the commissariat that had been created from above by the Petrograd Soviet established the most effective police power-a result made possible largely by Peshekhonov's energetic leadership and initiative. Yet the commissariat found itself under continual pressure from the revolutionized masses. In fact, its survival depended on constant accommodation to the mood of the "crowd." When Peshekhonov refused to surrender the weapons in the commissariat to a group of soldiers, he faced the rifles pointed at him by the surrounding soldiers. When he released the innocent victims charged with counterrevolutionary activities, he could not maintain authority "as the representative of the revolutionary power" unless he treated the accusers in a harsh manner. It is interesting to note that the most powerful commissar in the Petrograd District had to write in his memoirs: "All the power in essence completely rested in the hands of the crowd. The crowd executed it in the form of self-government, and many undoubtedly were convinced that this was truly the people's power."

Many factories in other districts also responded to the appeal of the Petrograd Soviet by electing the militia according to the prescribed ratio. Thus the Putilov Factory in the Narva District formed the workers' commissariat on February $28 .{ }^{47}$ The workers' militia was created also in the Neva Shipbuilding Factory, San-Galli, and the Obukhov Factory in the Kolomna District, and Dinamo, Simens-Schuckert, and Pobeda in the Moscow District. ${ }^{48}$ In these districts, however, the workers' influence remained weak, while the city militia established its effective control. In the industrial sections of the city the workers extended their influence in the formation of militia organizations, but in the administrative and the business centers of Petrograd the city militia almost exclusively dominated the police power. ${ }^{40}$ Although the workers also

45. Ibid., p. 306. It is not clear what relation existed between the commandant appointed by the Military Commission and the city militia. Admittedly, there is a lacuna in available evidence indicating any relation between Peshekhonov's commissariat and the city militia. Since the Duma Committee seized control of the Military Commission, which had been created on the initiative of the Soviet, the Military Commission made some efforts to restore order by assigning units to various districts. These efforts, however, remained ineffective, since the Military Commission was more preoccupied with the tasks of higher priorities-the occupation and the protection of the strategically important positions and buildings, and the restoration of the military discipline in the army units.

46. Ibid., pp. 288-89, 295, 299.

47. Startsev, Ocherki po istorii Petrogradskoi Krasnoi gvardii, p. 45; Kel'son, "Militsiia fevral'skoi revoliutsii," p. 172.

48. Startsev, Ocherki po istorii Petrogradskoi Krasnoi gvardii, pp. 45-46.

49. With the exception of the Rozhdenstvensky and Kolomna Districts, it is not known in detail how the city militia extended its authority to the districts. 
participated in it, the city militia mainly attracted the middle-class elements, particularly students. For instance, the militia in the Kolomna District was created by the soldiers and "citizens." 50 The representatives of the "workers from factories and mills, representatives of the sick-funds, consumer associations, city health department, and other social organizations" in the Rozhdestvensky District who met on March 2 called for "securing in the district order and safety of the population and organizing a special detachment (militia) for that purpose." ${ }^{11}$ Thus Petrograd was divided into two areas under conflicting police power: one area under the authority of the workers' militia which pledged allegiance to the Petrograd Soviet or under the commissariat directly created by the Soviet, and the other under the authority of the city militia created by the City Duma in close cooperation with the Duma Committee. This conflict of power at the local level indeed constituted the most fundamental reason for the birth of dual power. It is necessary, then, to examine the reactions of the Soviet Executive Committee and the Duma Committee to this conflict.

Already on February 28 the Soviet Executive Committee made clear its intention to cooperate with the Duma Committee in solving this conflict by sacrificing the independence of the workers' militia. At the second Soviet session held that day a keynote speaker, Iu. Steklov, representing the Executive Committee, stated that in order to achieve intended goals it was necessary "to rely not only on the workers" but also on other groups, without whose cooperation the Soviet power would not be able to hold out. ${ }^{52}$ The Executive Committee attempted to curb the workers' initiative to create their selfgoverning power, which it had encouraged just the day before. For instance, when the revolutionary committee from Sestroretsk, a small city fifteen miles north of Petrograd, appeared before the Executive Committee to request participation in the Soviet session, Bogdanov refused, explaining that one self-proclaiming committee composed merely of the workers without the participation of other social groups could not be recognized as a revolutionary selfgovernment. ${ }^{53}$ The Executive Committee decided to subordinate the workers' militia to the city militia on February 28 , although it is not certain whether this decision had the approval of the general session. The proclamation issued by the Socialist student groups, presumably with the approval of the Executive Committee, on the following day stated: "The Executive Committee of the Soviet of Workers' Deputies decided to unify the central organ of the workers' commissariats with this Duma organization [the city militia].... Remember,

50. Izvestiia, no. 4 (Mar. 3, 1917), pp. 4-5.

51. Izvestiia, no. 3 (Mar. 2, 1917), p. 4.

52. G. I. Zlokazov, Petrogradskii Sovet rabochikh i soldatskikh deputatov v period mirnogo razvitiia revoliutsii (fevral'-iiun' 1917 g.) (Moscow, 1969), p. 53.

53. Zlokazov, "O zasedanii Petrogradskogo Soveta," pp. 53-55. 
comrades, that you take part in the militia at the instruction of the Soviet of Workers' Deputies. Remember that the Soviet of Workers' Deputies is your highest authority."54 The decision to subordinate the workers' militia to the city militia while upholding its ultimate allegiance to the Soviet foreshadowed the famous policy formulated later by the Executive Committee of "conditional support" (poskol'ku-postol'ku) for the Provisional Government.

Nevertheless, the mere publication of a proclamation in Izvestiia could not convince the workers to accept the authority of the city militia. On March 2 the Executive Committee appointed two Mensheviks, V. P. Piatiev and Chernov (not to be confused with the famous leader of the S.R. Party), as liaisons between the Executive Committee and the city militia. These two, together with the city militia's secretary, Kelson, visited the headquarters of the workers' militia in various districts in an effort to persuade them to merge with the city militia. ${ }^{55}$ At the same time, in order to introduce some degree of uniformity in the procedures of all the militia organizations and, more important, to prevent the workers' militia from committing revolutionary excesses, these three men drafted the "instructions" regulating the procedures concerning arrest, use of firearms, and appropriation of automobiles, as well as clarifying the aims of the militia activities. Article 1 of the draft "instructions" stated, "The duty of a militiaman is to defend each and every one from all violence, offense, and arbitrariness"-a statement clearly intended to restrain the excesses of the workers' militia. On the other hand, the same article stipulated in the latter part of the paragraph, "A militiaman must understand that he is an executive organ of the new Free Russia and is obligated to combat all attempts at counterrevolution"-a statement designed to lure the workers' militia to the city militia by emphasizing common purposes. ${ }^{50}$ On March 3 the city militia convened the first general meeting of the district commissars in the City Duma, to which the representatives of the workers' militia were also invited. More than fifty commissars who attended this meeting approved the draft "instructions" as well as the incorporation of the workers' militia into the city militia. ${ }^{57}$ With the unification of the two militia organizations the city militia was renamed the "people's city militia" (gorodskaia narodnaia militsiia). The unification was made final on March 7 by the Executive Committee's reconfirmation of the February 28 decision "on the condition that the Soviet reserves the right to control its candidates for militiamen." 58

54. Izvestiia, no. 2 (Mar. 1, 1917), p. 3.

55. Kel'son, "Militsiia fevral'skoi revoliutsii," p. 167.

56. Ibid., p. 167.

57. Ibid., p. 168; Startsev, Ocherki po istorii Petrogradskoi Krasmoi gvardii, p. 48.

58. "Protokoly Isp. Kom. Petrogr. Sov. Rab. i Sol. Dep. za 3-11 marta 1917 g.," in "Fevral'skaia revoliutsiia v dokumentakh," Proletarskaia revoliutsiia, 1923, no. 1 (13), p. 324. 
An examination of the Executive Committee's attitude toward the conflict of police power reveals two interesting points. First, not only had the Executive Committee no intention of seizing power, by using the already established power of the workers' militia, but it also willingly helped the city militia to incorporate the workers' militia, despite the latter's reluctance to accept this policy. The Executive Committee's willingness to compromise was so persistent as to give the impression that it even feared the spontaneous popular movement expressed in the form of the workers' militia. Second, while pursuing a policy of cooperation with the city militia, the Executive Committee always qualified its support by demanding the ultimate allegiance of the workers to the Soviet. In order to have the workers accept the unpopular policy of compromise, the Executive Committee needed to assure them that it was not betraying their expectations. At the same time, the Executive Committee was well aware that the strength of the Soviet largely stemmed from the support of the masses. Though it was anxious to see a "bourgeois" social order established, it had no intention of diminishing its strength and losing its effectiveness as a pressure group. Hence the Executive Committee took a contradictory position. On the one hand, it lent its support to the Duma Committee to smooth the way for the latter to form a stable government. But on the other hand, it jealously guarded its ultimate claim to the allegiance of the insurgents. Nor was there total unanimity among the leading members of the Executive Committee on this issue. There existed a difference in nuance between Sukhanov, who emphasized the need to cooperate with the Duma Committee, and Sokolov, who was more interested in consolidating the power base of the Soviet-a difference which was reflected in the Executive Committee's contradictory policies.

The decision to amalgamate the workers' militia with the city militia, however, invited strong protest from the workers. On March 8 the Executive Commission of the Vyborg District Soviet passed a resolution calling for nonacceptance of the personnel appointed by the city militia to serve on the workers' militia. ${ }^{59}$ The merger of the two organizations apparently led to the geographical reorganization of the workers' militia in some districts. The workers considered this attempt by the city militia a political move designed to undermine the strength of the workers' militia. On March 8 the general meeting of the Narva District Soviet, which discussed the "interference of the city militia in the matters of the district," demanded that the city militia "not divide the districts, and above all not bring about disorganization among the ranks of the militia and let them stay in the buildings which they had occupied even when there existed no militia in the city."

59. Raionnye sovety Petrograda, 1:124.

60. Ibid., 2:96. 
passed at the workers' meeting of the Cable Factory on March 12 more directly protested the merger as "a campaign against the workers' militia," and further stated: "This campaign, started by the bourgeois City Duma, provokes in us a strong protest. We maintain that at the present moment, when before the democracy stands a struggle for a democratic republic, a struggle with the remnants of tsarism, and constitutional monarchy designed by the bourgeoisie, the workers' militia must take precedence over the philistine militia organizations." ${ }^{01}$ The deep dissatisfaction with the merger was also expressed in the meeting of the Executive Commission of the Vasilievsky District Soviet on March 26, although the overwhelming sentiment of the Executive Commission favored the subordination of the workers' militia to the city militia. ${ }^{62}$

Met with these strong protests, the united efforts by the Soviet Executive Committee and the city militia to form a single militia organization in Petrograd fell short of the desired goal. Although the workers' militia reluctantly accepted its organizational subordination to the city militia in a theoretical sense under the pressure of the Executive Committee, it maintained for all practical purposes its independence and autonomy, continuing to control the workers' sections of the city exclusively without any interference from the city militia. According to Startsev's figures, approximately twenty of the eightyfive militia centers that existed in Petrograd on March 19 were under the influence of the workers' militia, and the workers' militiamen numbered approximately ten to twelve thousand out of a total of twenty thousand militiamen in Petrograd. ${ }^{63}$ The workers' commissariat consisted exclusively of the workers' representatives, and refused to allow the appointed representatives from the city militia to join its staff, as the resolutions adopted by the Vyborg District Soviet and the Narva District Soviet clearly indicate. In the industrial sections of the city, the workers' commissariats constituted the sole, highest power, establishing the workers' self-government and fulfilling the most direct day-to-day administrative function, thus filling the power vacuum created by the elimination of the tsarist police.

A militiaman in the city militia was employed by the city (receiving a salary from the city of one ruble per hour), but a militiaman in the workers' militia kept his regular job and received an allowance for militia duties from the management of his factory, in addition to the regular salary while absent from work for militia duties. ${ }^{64}$ In most cases militiamen were elected through

61. Revolintsionnoe dvizhenie v Rossii posle svergheniia samoderzhaviia, p. 488.

62. Raionnye sovety Petrograda, 1:83-84.

63. Startsev, Ocherki po istorii Petrogradskoi Krasnoi gvardii, p. 52.

64. Ibid., p. 55; Raionnye sovety Petrograda, 1:86, 2:111. The salary the militiamen received from their employers while at militia duties apparently was not their full salary. The workers of the Putilov Factory demanded only half. 
a lottery system at a general workers' meeting in a factory according to the ratio prescribed by the Executive Committee of the Petrograd Soviet. In contrast to the city militia, which was a permanent job, the workers regarded militia duties as temporary civil responsibilities; hence there was a great turnover in membership in the workers' militia. For instance, in the Petrograd Metal Factory in the Vyborg District, out of a cumulative total of 470 militiamen who were registered from March to July 1917 only ten served the full four months, and full membership in the militia did not exceed $140 .{ }^{65}$ Despite the "instructions" agreed upon regarding the procedures of militia operation, the workers' militia conducted its business autonomously. In addition to the maintenance of order in its jurisdiction, it also inherited some of the administrative work previously done by the police, such as the registration of residents and keeping records of the incoming and outgoing population. ${ }^{60}$ All this military, judicial, and administrative work was carried out by the inexperienced workers themselves. Confusion and excesses must have been astounding. Yet this system gave the workers a sense of participation in building a new social order (a privilege they had long been denied under tsarism), hence a great sense of pride in themselves and of solidarity with their fellow workers. The workers' militia became a training ground for revolution, where thousands of workers were exposed to political propaganda, caught up with the latest political developments through their daily conversations, and learned all sorts of practical knowledge necessary for a revolution. In some cases the workers' militia even hired, at the employers' expense, a military instructor for the military training of militiamen. ${ }^{67}$ A great turnover in the workers' militia therefore facilitated the spread of revolutionary sentiments among the workers. The city militia lacked this vitality. It created a permanent, professional police force, which, however, had no connection with the basic organizations and institutions of the people's daily lives. In contrast, the workers' militia had deep roots in factories, the most fundamental social and economic institution in society, which even the revolutionary upheavals failed to disrupt. Thus, despite the nominal superiority of the city militia, the workers' militia was destined to overpower its rival.

An examination of the problem of weapon-control vividly demonstrates the importance of guns in the revolutionary power play. The workers acquired weapons in the process of their participation in the insurrection on February 27, when they occupied the Arsenal, weapon and cartridge factories, and police stations. Undoubtedly some of the weapons fell into the hands of irresponsible citizens, and even criminals, thus creating a public menace. ${ }^{68}$

65. Startsev, Ocherki po istorii Petrogradskoi Krasnoi gvardii, pp. 57-58.

66. Ibid., pp. 55-56.

67. Ibid., p. 57.

68. Peshekhonov, "Pervyia nedeli," pp. 273-74. 
The Duma Committee, the Petrograd Soviet, and the workers' militia differed in their approaches to dealing with this problem.

The Duma Committee felt that the greatest danger lay not in the possession of weapons by a small group of irresponsible citizens and criminals, but rather in the fact that the masses of insurgents in the streets were now armed. In its opinion, only a few authorized institutions-the Military Commission and the city militia-should possess weapons. The Duma Committee therefore consciously treated this problem as a part of the problem of power. The successful seizure of weapons from the hands of the insurgents would assure the creation of a stable government strong enough to steer its course without yielding too much to popular pressure. Thus, as soon as the Duma Committee took over the Military Commission, it quickly took measures to protect the military supply depots and munition factories from the insurgents. ${ }^{69}$ Early on the morning of February 28 two members of the Duma Committee, B. A. Engelhardt and A. A. Bublikov, issued the following order in Rodzianko's name to the Petrograd Garrison troops: (1) all individual soldiers and military units should return to their barracks inmediately; (2) all officers should return to their units and take all necessary measures to restore order; and (3) all commanders of units should appear at the Tauride Palace at eleven o'clock in the morning in order to receive further instructions..$^{70}$ Rodzianko's order was clearly intended to restore order and discipline in the military units on the basis of the old system. Although the order did not specifically contain a provision concerning the confiscation of weapons from the soldiers, the insurgents understood well that the restoration of order and discipline under the leadership of the old officers would definitely lead to that conclusion. The first to react to Rodzianko's order were the workers' deputies to the Soviet, who at the second general session on February 28 angrily denounced it as a counterrevolutionary provocation, with some even demanding Rodzianko's immediate arrest. Bogdanov, Steklov, and other Executive Committee members tried to neutralize the protest by introducing a motion to inquire about this order through Kerensky and Chkheidze, the Soviet's official representatives to the Duma Committee, but this motion was not enough to quiet the deputies' anger. ${ }^{71}$ The workers clearly interpreted Rodzianko's order not only as aimed at the soldiers but also as an attempt directly designed to confiscate

69. "Fevral'skaia revoliutsiia v Petrograde," pp. 64, 67, 69, 76, 90.

70. Burdzhalov, Vtoraia russkaia revoliutsiia, p. 275. Boyd mentions that this order was issued on February 27 ("The Origins of Order No. 1," p. 362). Since the Duma Committee did not take over the Military Commission until two o'clock on the morning of February 28, it could not have been issued on February 27.

71. M. Rafes, "Moi vospominaniia," Byloe, 19 (1922): 193; Zlokazov, "O zasedanii Petrogradskogo Soveta," pp. 58-60. It is interesting to note that the minutes of the Soviet session as reported in Izvestiia do not mention anything about this debate. See Izvestiia, no. 2 (Mar. 1, 1917), p. 2. 
weapons from the hands of the workers. More important, however, this order provoked a violent reaction from the soldiers, who for the first time since February 27 attended the Soviet session en masse on March 1 and dictated their demands to the Petrograd Soviet-an event which precipitated the issuance of Order No. $1 .^{72}$ Faced with this unexpected violent reaction from the masses, the Duma Committee was forced to retreat, specifying that the original order should not be construed as a demand for the confiscation of weapons, and denouncing the "rumor" to that effect as a "provocational lie."73

On March 1 the head of the city militia, Kryzhanovsky, issued a proclamation appealing to the citizens to surrender weapons to the city militia. ${ }^{74}$ Unlike Rodzianko's order, this was an appeal begging cooperation and not implying any punitive actions. Only a small number of citizens responded to this proclamation, and the workers simply ignored it. The city militia acquired by voluntary surrender only 108 rifles and 307 revolvers and pistols. Of the 300 persons who voluntarily surrendered their weapons, 223 did so in the central districts of the city (Admiralty, Spassky, Kazan, Liteiny, and Kolomna), while only fifteen persons in the Petrograd District and seven persons in the Vyborg District responded favorably to Kryzhanovsky's appeal. ${ }^{75}$ Thus it was apparent by March 1 that the attempts by the Duma Committee and the city militia to confiscate weapons from the masses had failed. They realized that without antagonizing them to the extent that a military confrontation would be inevitable, they could not disarm the masses. Having burned their fingers, they now proceeded to reach a modus vivendi with the workers' mili-

72. See Boyd, "The Origins of Order No. 1," pp. 362-72; V. I. Miller, "Nachalo denokratizatsii staroi armii $\mathrm{v}$ dni fevral'skoi revoliutsii (Zasedanie Petrogradskogo Soveta 1 marta 1917 g. i prikaz No. 1)," Istoriia SSSR, 1966, no. 6, pp. 26-43.

73. Engelhardt's statement in Izvestiia, no. 3 (Mar. 2, 1917), p. 1.

74. Iavestiia, no. 5 (Mar. 4, 1917), p. 4.

75. Startsev, Ocherki po istorii Petrogradskoi Krasnoi gvardii, pp. 50-51. A comparison between these figures and the total number of weapons seized by the insurgents during the insurrection leads to the obvious conclusions that Kryzhanovsky's appeal had no effect at all and that the insurgents kept their weapons. According to I. I. Mints, the weapons captured by the insurgents from the Arsenal alone numbered 40,000 rifies and 30,000 revolvers, not to mention the weapons taken from the various regimental armories. More than 2,000 shells and 2,000,000 cartridges fell into the hands of the masses. See I. I. Mints, Istoriia Velikogo Oktiabria, 3 vols. (Moscow, 1967), vol. 1: Sverzhenie samoderzhaviia, p. 538. In addition, the workers of the Sestroretsk Weapon Factory handed most of the weapons they had captured from the factory stock to the insurgents in Petrograd (1,247 rifles, 48 sporting guns, 64 pistols and revolvers, and 100,000 cartridges). See V. A. Tsybul'sky, "Rabochie sestroretskogo zavoda v 1917 g.," Istoriia SSSR, 1957, no. 4, p. 144. Moreover, despite the opposition from the Duma Committee as well as from the Soviet Executive Committee, the Military Commission was compelled to surrender to the insurgents (under their strong pressure) the weapons that came under its control. Zlokazov states that the Military Commission gave the workers 24,000 rifles and 400,000 cartridges between March 2 and March 4. See Zlokazov, Petrogradskii Sovet rabochikh i soldatskikh deputatov, p. 55. 
tia, a policy which explains the city militia's eagerness to absorb the workers' militia into its organization.

Though the Duma Committee and the city militia wished to disarm the masses, the workers' militia took a directly opposite position, advocating the transfer of weapons to the masses. How, then, did the Executive Committee of the Petrograd Soviet react to this conflict? On February 28, when the delegates of the workers' militia in the Vyborg District approached the Executive Committee with the request for weapons, they met a flat rejection from the latter on the excuse that the Military Commission itself did not possess a sufficient quantity of weapons. ${ }^{76}$ The Executive Committee's position on this matter was made even clearer in its proclamation printed in Izvestiia on March 1. The proclamation addressed to the workers stated:

The working class is experiencing an urgent need of weapons at the present moment. The success of the struggle is closely connected with the degree of organization of the working class. Therefore, the Soviet of Workers' Deputies requests all the comrade workers who possess weapons to surrender them to the commissars appointed by the Soviet of Workers' Deputies in various districts. If for some reason it is not possible, then it is necessary to hand the weapons in to the Soviet of Workers' Deputies located in the building of the State Duma (Tauride Palace) ${ }^{77}$

Under the veneer of revolutionary phraseology the proclamation clearly revealed the Executive Committee's intention to take the weapons away from the insurgents. Yet the Executive Committee did not go so far as to demand the transfer of weapons to the Military Commission or the city militia, since it could not dispel its fear that the "bourgeoisie" might choose to stand for a counterrevolution. Hence, on this issue as well, the Executive Committee took a middle road; while maintaining that the individual insurgents should surrender their arms, it nevertheless advocated the control of weapons by the Soviet or by the commissars appointed by the Soviet. But the attempts of the Duma Committee and the city militia as well as the Executive Committee to dispossess the masses of weapons were frustrated by the workers' stubborn resistance. On March 5, for instance, the workers of the Petrograd Metal Factory, pointing out the danger of an internal enemy to the revolution, demanded the transfer of weapons to the workers' militia. ${ }^{78}$ Both the Petrograd Soviet and the city militia soon began to yield to the persistent pressure of the workers' militia for more weapons. The commissar of the First Vyborg Subdistrict, Botsvadze, frequently threatened "Comrade" Kryzhanovsky with

76. Zlokazov, "O zasedanii Petrogradskogo Soveta," p. 52.

77. Isvestiia, no. 2 (Mar. 1, 1917), p. 3.

78. Revoliutsionnoe dvizhenie $v$ Rossii posle sverzheniia samoderzhaviia, p. 462. 
the warning: "Give us weapons, or we will blow up this place now." To this threat, Kryzhanovsky readily yielded. ${ }^{79}$ According to Kelson, more than half of the weapons available to the city militia went to the Vyborg District. ${ }^{80}$

An inherent weakness of the Duma Committee and the city militia was clearly revealed by their failure to carry through their original intention to deprive the masses of these weapons. Only one measure could have accomplished this goal-a military showdown. But neither the Duma Committee nor the city militia was prepared to take this risk. Once they abandoned their original policy their only choice was to accept the existence of the workers' militia, hoping to exert some control over it, if not to dominate. This policy, however, left the Duma Committee and the city militia wide open to popular pressure. The Executive Committee of the Petrograd Soviet also advocated the seizure of weapons from the insurgents, although it refused to support the bid of the Duma Committee and the city militia for the exclusive right to control weapons. This position was consistent with the Executive Committee's implicit assumption that a Provisional Government should be formed from the "bourgeoisie" without the participation of the "proletariat." Yet its actions were motivated not only by its desire to help the "bourgeois" forces organize a new government but also by its fear that popular pressure might push it to seize power-a course which it was not capable of pursuing and had no intention of following. Indeed, the leaders of the Executive Committee were as scared as the Duma Committee leaders of the uncontrollable energy of the masses, which defied their rational approach and the "objective" law of history. Despite its intention, however, the Executive Committee could not enforce its decision without alienating the masses. As long as it wished to maintain its effectiveness, it had to yield to popular pressure.

The analysis of the formation of the militia in the February Revolution leads us to some important conclusions concerning the birth of dual power. The essential nature of dual power is not the conflict between the Duma Committee (the Provisional Government after March 2) and the Executive Committee of the Petrograd Soviet, as it has been hitherto argued, but rather the conflict between the authority emanating from the Duma Committee/Provisional Government and the self-government established by the insurgent masses. These two conflicting authorities geographically divided their spheres of influence in Petrograd. Although the Provisional Government succeeded

79. Kel'son, "Militsiia fevral'skoi revoliutsii," p. 175.

80. Ibid. The surrender of weapons to the workers' militia was discontinued in April, when the commander of the Petrograd Military District, General Kornilov, refused city militia access to the military supply depots. According to Startsev, the workers' militia received no fewer than 1,000 rifles and 650 revolvers and pistols from the city militia from March to the middle of April. See Startsev, Ocherki po istorii Petrogradskoi Krasnoi gvardii, pp. 54-55. 
in establishing a nominal power, organizationally subordinating the workers' militia to the city militia, its authority suffered an inherent weakness. The new government could not rely on the institutional structure of the old regime, which had been greatly disrupted by the revolutionary upheaval, and it also failed to establish direct connections with the masses. Decrees and proclamations were limited in their effectiveness; the naked force of coercion was unavailable. Quite in contrast, the incipient self-government of the workers came into existence right in the midst of the daily life of the masses, and therefore had promising revolutionary vitality and potentialities. Yet its force was extremely limited in a national scale, particularly when the attitude of the soldiers at the front still remained in question. Nor had the majority of workers, who had established an enclave of autonomy in the capital, yet begun to translate their immediate feelings and grievances into conscious revolutionary programs. The workers, with a few exceptions, could not offer any alternative to the Executive Committee's policy toward the problem of power, despite the manifestations of their latent radicalism on a number of specific issues. The Provisional Government, however, could not destroy even this negligible force of the workers' militia, since it and the Duma Committee from the beginning had sought to attain revolutionary legitimacy. Thus the fundamental confict between the two powers was, peculiarly, not immediately disrupted by one side's bid to devour the other.

The Soviet Executive Committee's policy provided a crucial clue to the temporary stalemate in this conflict. Refusing to strive for the seizure of power by relying on the overwhelming support of the insurgents in Petrograd, it willingly assisted its opponent to establish power. This compromising policy, which invited sharp criticism from the workers, however, was based on sound political judgments. The Petrograd Soviet could not have seized power without precipitating a civil war. The Soviet's decision to seize power in March, when the revolutionary forces had not been sufficiently consolidated, while the army at the front still remained potentially a viable force against the capital, would have brought the revolution to a disastrous end. ${ }^{81}$ The dual power that emerged after the February Revolution was therefore an accurate reflection of the political relations between these three groups-the Provisional Government, the Soviet Executive Committee, and the Petrograd workers.

81. For a more detailed discussion on this matter see my article, "The Problem of Power in the February Revolution of 1917 in Russia." 